[Codd, J. (2004). Export Education and the Commercialisation of Public Education in New Zealand. New Zealand Annual Review of Education, 13, 21-41]

\section{Export Education and the Commercialisation of Public Education in New Zealand}

\author{
JOHN CODD
}

\section{Abstract:}

Public education in New Zealand has become a globally marketable commodity, with the "export education" industry becoming a major new area within the national economy. While many schools, both primary and secondary, have become financially dependent on the income derived from foreign fee-paying students, scant attention has been given to the educational outcomes of this commercialisation of the public education system. It is a trend that began in the early 1990s with the policies of decentralisation marketisation and privatisation and has been accelerated under the influences of globalisation and the rise of the new knowledge-based economy. Thus, education has now become a billion dollar export industry. This extension of globalisation in to the domain of education produces an agenda for educational reform that raises fundamental questions about the purposes of public education. To what extent, for instance, should global economic purposes have priority over those of citizenship and national identity? The article explores the nature of globalisation and examines the international marketisation of education and the effects of this rapidly growing trend on education in New Zealand, including the implications of the export education industry and the General Agreement on Trade in Services (GATS).

$\square$ ducation in New Zealand has become a major export industry.

It is estimated that foreign fee-paying (FFP) students have created up to 20,000 jobs and are now contributing 1.7 billion dollars per year to the New Zealand economy. At the current rates of growth, this newly emerged industry, already the fifth largest, could be earning five billion dollars per year within the next decade (Asia 2000 Foundation, 2003). This is phenomenal growth when it is compared with New Zealand's largest export earner, the dairy industry, which currently earns just over six billion dollars per year. Unlike the dairy industry, however, the education industry exports services rather than products, and it now provides nearly all of those services within the country across the full range of educational institutions, both public and private, including primary and secondary schools, polytechnics, universities and private training establishments.

Ministry of Education figures for 2002 (cited by the Asia 2000 Foundation) show that there were approximately 82,000 foreign fee-paying students enrolled in New Zealand educational institutions, mainly from China (almost 40 percent), South Korea (almost 20 percent) and Japan (16 percent). While the majority of these students were enrolled at the tertiary level, according to 1 July statistical returns there were 15,259 FFP students in New Zealand schools (22 percent in primary schools and 78 percent in secondary and composite schools). This represents a 45 percent increase on 2001 figures and a 320 percent increase since 1996. Thus, by 2002, 20 percent of all primary schools had at least one FFP student enrolled, while FFP students were enrolled at 71 percent of secondary schools (Education Review Office, 2003).

What this picture clearly shows is a rapidly increasing commercialisation of New Zealand's public education system. It is a development that appears to have taken government policy makers by surprise. Indeed, policy responses in this area have been almost entirely reactive rather than proactive, and there has been no attempt to reconcile the promotion of education as an export industry with the traditional purposes of public education. This is not at all surprising, given the present Government's dual and somewhat contradictory commitments both to fostering national identity and to joining the global knowledge-based economy.

Historically, public education in New Zealand, at least since the 1930s, has been based on communitarian ideals of egalitarianism and social welfare. Public education contributed directly to the maintenance of social democracy through building communities of literate and informed citizens. The primary aims of educational policy, while not always reflected in social realities, were to provide for equality of opportunity and to foster the values of democratic citizenship. Within the Keynesian welfare state, with its goals of full employment and social security, the primary function of the public education system was to provide the social foundation for a 
democratic polity and a stable mixed economy. However, with the economic collapse of the welfare state in the mid 1980s and the rise of neoliberalism, educational policy has been subsumed, to a large extent, within economic policy. Consequently, the radica transformation of New Zealand society that has taken place over the past twenty years has had profound effects upon the political, economic and social contexts of education.

In the discussion that follows, it is argued that the commercialisation of public education that we are now witnessing in New Zealand should be seen as the latest phase of a neoliberal agenda for educational reform that began with the policies of decentralisation, marketisation, privatisation and the general subordination of education to economic objectives. This trend has been accelerated under the influences of globalisation and the rise of the new knowledge-based economy. It is assumed, within this context, that investment in education by the state can produce measurable returns on indicators of increased competitive advantage and economic growth. Predictably, therefore, education has now become a major export industry. This extension of globalisation into the domain of education raises fundamental questions about the purposes of public education. To what extent, for instance, should global economic purposes have priority over those of citizenship and national identity? The following discussion explores the various dimensions of globalisation and considers how these might relate to public education and the nation-state. In this respect, it examines the international marketisation of education and the effects of this rapidly growing trend on education in New Zealand, including the implications of the export education industry and the General Agreement on Trade in Services (GATS).

\section{The Neoliberal Reform Agenda}

In New Zealand, the neoliberal revolution followed the election of the fourth Labour government in the "snap" election of July 1984. At this time, the Treasury became the most powerful bureaucratic influence in state policy making, pursuing an agenda based upon human capital theory, public choice theory and transaction cost economics. Within the discourses of neoliberalism the economy is the primary source of legitimation for the state's role in education. From this ideological position, New Zealand Treasury officials argued that education should no longer be seen as an investment by government in the wealth-generating capacity of the nation, but as a drain on the nation's resources, keeping taxation high, stifling investment, and providing benefits mainly to the individuals who received it, rather than to the nation as a whole (Codd, Gordon \& Harker, 1997). Thus, the Treasury's stated position was as follows:

Education is never free as there is always an opportunity cost to the provider. Those who provide the inputs to formal education naturally seek to defend and develop their own interests. Hence, formal education is unavoidably part of the market economy and the Government can afford to be no less concerned with the effectiveness and "profitability" of its expenditure on education, in relation to the state's aims, than private providers would be in relation to their own. (Treasury, 1987, Vol. 1, p. 133).

This view of education is in sharp contrast to the traditional Keynesian view in which education is considered essential to the state's role in providing a cohesive and stable social context necessary for sustaining the effective operation of markets. In contrast, neoliberalism is hostile to the Keynesian welfare state, which it takes to be a cumbersome bureaucratic apparatus that not only destroys individual initiative but also stifles economic prosperity. Welfare, in the neoliberal view, should be replaced by economic growth because it is only by increasing the overall economic wealth of a society that the lot of its less advantaged members can be improved (Giddens, 1998). But neoliberalism is also hostile to social democracy. This is not surprising, given that the welfare state is the product of social democracy. It is the institutional embodiment of the struggle for citizenship rights - that is, rights to health, education and employment opportunities - within a social environment of collective responsibility and national identity. In contrast, neoliberalism emphasises individual rights to property ownership, legal protection and market freedom, within a social environment of enterprise and competition. Each of these social constructions of the citizen has particular implications for education policy and the role of the state in the provision of public schooling.

The restructuring of education that was to follow Treasury's prescriptions had the declared purpose of making the system more efficient and more responsive to its "clients", to alter the relationship between providers (teachers) and consumers (parents). A further related purpose was to shift the basis of educational accountability 
from a focus on inputs and process to a focus on outcomes and products. The initial restructuring began in 1989 and focused on decentralisation, self-management of schools, parental choice, governance and accountability. It involved reducing the size of the central bureaucracy, abolishing regional education boards and converting schools into self-managing units competing with each other for students and resources. Thus, the key elements of a market environment for the provision of education were established by 1990

During the 1990s education policy in New Zealand was strongly influenced by the discourse of economics. Not only has this influence been evident in national policies but, as Marginson (1997a, p. 4) points out, economics "now directly shapes the work of educators through the greater vocationalism, the growing role of employers in educational practice, the use of output and performance measures, and real and simulated markets." To a large extent, education under neoliberalism has been commodified in the form of human capital.

In human capital theory, the economic value of education is measured by the increase in the earning power or productive capacity of individuals. Empirically it can be shown that the average earnings of workers with more years of formal education are higher than those with fewer years. Moreover, when other variables are controlled (e.g., ethnicity, class or motivation) there remains some variance that can be attributed directly to the amount of education acquired. This equates with human capital which is measured not directly but indirectly through what is produced. Human capital theorists acknowledge that education has other effects not so invested in individuals, and these are referred to as externalities. For example, education may have spillover benefits for others who are not actually acquiring the education (such benefits might come from higher general levels of literacy, or improved professional services, etc.) but these are not sufficient for the neoliberal economist to define education as a "public good".

In the economic sense, public goods are non-marketable and cannot be appropriated byindividuals. Any individual's consumption of the public good cannot exclude any other individual from consuming the good. Education, however, is what Hirsch (1976) termed a "positional good" in that it confers relative advantage on the recipient. Those who acquire education (particularly higher education) have an advantage in the competition for scarce positions in the job market or the social hierarchy. Thus, the gaining of positional advantage by some results in a loss of advantage for others. It is a zero-sum game.

Marginson $(1993,1997 \mathrm{~b})$ argues that education can take the form either of a public good that is non-marketable or of an individualized positional good that is subject to competition, exclusion and sale for profit. Non-market education may be promoted by reforms that increase educational access and equality of opportunity, whereas the marketisation of education is promoted by policies based on user-pays and commercial enterprise. The market approach, moreover, becomes self-fulfilling. Thus:

The growing resort to company sponsorship and "user payments" increases the market component of education. In turn this increases the degree to which education fosters rivalry and exclusion, and position and selection at the expense of the academic and the democratic. (Marginson, 1993, p. 177)

Construing education as an economic production function is another common device of the neoliberal economist. This derives from the economic theory of the firm (Figure 1). Within this theory, business firms operating in a competitive market are considered to be

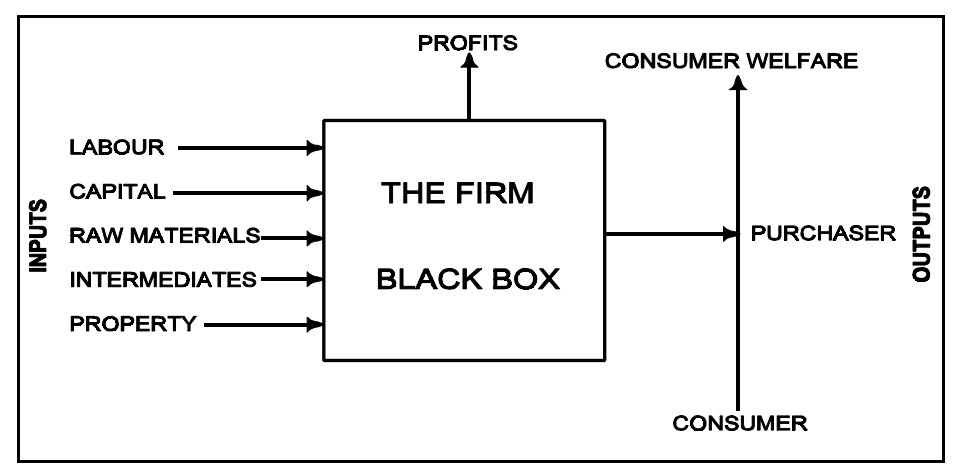

Figure 1 The economic theory of the firm (Easton, 1999, p. 150)

input-output systems. A measure of a firm's efficiency or profitability is the extent to which it combines its inputs in order to maximize its outputs. The process through which it achieves this is referred to as a production function, that is, a mathematical description of the production process through which a given set of inputs results in measurable outputs (Marginson, 1993). 
When this theory is applied to education it gives rise to what Easton (pp. 149-157) has called "the commercial theory of the school" (Figure 2). In the New Zealand education reforms, this theory has been enormously influential in shaping policies of governance and accountability (Smelt, 1998). The school, or other educational institution, is viewed as a "black box" and the educative process is considered to be a production process in which resource inputs are used to produce measurable educational outputs.

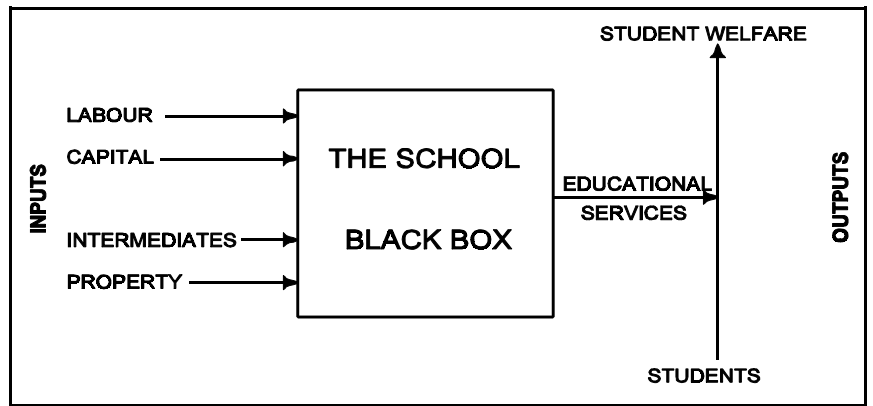

Figure 2 The commercial theory of the school (Easton, 1999, p. 153)

In many ways New Zealand schools now function like small businesses. They are required to carry out strategic planning, to exercise efficient financial management, and to engage in entrepreneurial activities. Teachers are still paid centrally on the basis of staffing entitlements, although additional staff may be employed from locally generated funds. Each school receives from the Ministry of Education a bulk operating grant based on roll numbers. The Ministry also makes a number of special grants for particular purposes, such as curriculum initiatives, special education or defined special needs (e.g., having a high percentage of Maori or Pacific Islands students). Other sources of income may derive from fundraising, parental donations, sponsorships, or the marketing of educational services to fee-paying foreign students. Hence, schools compete for resources in what can only be described as a commercial environment. According to Easton, a New Zealand economist who clearly does not subscribe to the economics of neoliberalism, the purpose of such commercialisation is not only to improve educational efficiency in the utilisation of resources, but to change the very nature and purpose of education. Thus, he argues that:
A central reason for the commercialisers' anxiety to change the education system is to stamp out broader values, and bring the education system's objectives - as well as its practices - into line with commercialist values. (Easton, 1999, p. 156)

Thus, in the 1990s, under the influence of neoliberalism, the central focus of education policy shifted from citizenship to the national economy and the role of the schools in fostering an "enterprise culture" so that, in the words of the then Minister of Education, Hon Lockwood Smith, education would "deliver the skills and attitudes required for New Zealand to compete in an increasingly competitive international economy" (Ministry of Education, 1991, p. 2). This was to herald a new era in which the national interest would be redefined within the context of international economic competitiveness. Consequently, by the end of the 1990s, the New Zealand government, having embraced economic globalisation, had become committed to the goal of creating a knowledge economy.

\section{The Export Education Industry}

Within the market environment there have been obvious incentives for schools to increase their income by enrolling what are referred to as foreign fee-paying students (FFPS). With the implementation of decentralisation and self-management in 1990, schools were, for the first time, legally required to recover the costs of tuition for all foreign students (i.e., those without citizenship or residency rights). In the early 1990s, the numbers of students, though relatively small, began to rise quickly, with most coming from the Asian region.

Dale and Robertson (1997, p. 221) report that between 1992 and 1995 the numbers of FFP students in secondary schools almost trebled. From 1997-99, there was a sudden drop in numbers due to the Asian economic crisis, but since 1999 growth per annum has been consistent at around 45 percent (Table 1). Similar growth is evident in the tertiary education sector, where there are much greater numbers overall. The magnitude of this development within the New Zealand education system can be appreciated when the numbers are extrapolated to a population the size of the United Kingdom. New Zealand, with a population of 4 million, has 82,000 FFP students. If the UK had a comparable number, with a population of 60 million, it would have 
Table 1 Foreign fee-paying students at New Zealand schools

\begin{tabular}{lccc}
\hline Year & Number & Rate of Increase/Decrease \\
\hline 1996 & 4768 & & \\
1997 & 5468 & $+14.7 \%$ & \\
1998 & $4729^{*}$ & $-13.5 \%$ & $*$ Asian economic crisis \\
1999 & 5044 & $+6.7 \%$ & \\
2000 & 7191 & $+42.6 \%$ & \\
2001 & 10,555 & $+46.8 \%$ & \\
2002 & 15,259 & $+44.6 \%$ \\
\hline
\end{tabular}

(Source: Ministry of Education Statistics)

1.2 million FFP students. Currently, there are approximately 2 million world-wide (Asia 2000 Foundation, 2003).

The growth in FFP students over the past decade is not something that was planned with the restructuring reforms of 1989 . Nevertheless, it is a direct consequence of the marketisation/ privatisation agenda that lay behind those reforms (Fiske \& Ladd, 2000). Throughout the 1990s, services were marketed by New Zealand International Education Limited (NZIEL), a business enterprise supported by membership subscriptions. This was later to become Education New Zealand (EdNZ). In July 2000, after a decade of rapid growth, the export education industry was officially acknowledged by the Government when Tourism New Zealand and Trade New Zealand entered into a partnership with Education New Zealand to form the New Zealand International Education Marketing Network, with a brief to develop a New Zealand-wide brand and marketing strategy (Ministry of Education, 2001, pp. 19-20; Shepheard, 2002, p. 59). Government funding for marketing was provided and what came to be called Export Education was recognised as a major new element within the New Zealand economy.

In August 2001, the Ministry of Education produced a scoping report entitled, Export Education in New Zealand: A Strategic Approach to Developing the Sector. In this report, "export education" is defined as "a transaction across borders involving the provision of education services in exchange for financial consideration" (Ministry of Education, 2001, p. 8). For the first time, the New Zealand
Government declared its intention "to ensure high quality provision and more balanced growth, in what is an important and promising industry" (Ministry of Education, 2001, p. 5). While referring to a young and rapidly growing industry, the report also acknowledges that there is "a need to ensure that domestic students" interests are protected, Crown interests are not put at risk and that export education objectives do not compromise other social and economic priorities" (Ministry of Education, 2001, p. 11). The listed benefits of developing this industry are generally more economic than educational in nature and in the list of risks there is an explicit recognition of the "potentially adverse impact on domestic students." Moreover, the report observes that:

Most export education providers are state owned or dependent on state funding, and their participation in international education is marginal to their primary function - the education of domestic students. (Ministry of Education, 2001, p. 22)

The impact of this kind of international commercialisation on some schools has without doubt been considerable, although the effects remain to be systematically evaluated. Many state schools in New Zealand are now highly dependent on the income derived from FFP students. It has been reported recently that the 10 state schools with the highest numbers of FFP students earned more than $\$ 1$ million each from the fees, and one of those schools in the Auckland area earned $\$ 2$ million from its 202 foreign students. The money, it is claimed, is spent on extra teachers, resources and maintenance (Grunwell, 2003). The principal of a large regional secondary school stated recently that the Board of his school was considering increasing the number of FFP students from 58 to 75 in 2004 to supplement the school's operations grant. He is quoted as saying, "We can't run our programmes with the staffing entitlement" (Nash, 2003).

To date, there has been very little research on the educational effects of international commercialisation on teaching methods, curriculum, learning styles, school culture, language needs or ethnic relationships. There has been recognition, however, of the need for some regulatory control over standards of provision with the development by the Ministry of Education of a Code of Practice for the Pastoral Care of International Students. This code came into force in March 2002, with a transition period of six months. The Code has been revised subsequently in response to changing circumstances and an 
International Education Appeal Authority(IEAA) has been established to deal with alleged breaches of the Code. This regulatory framework could be taken as evidence that export education is now an established element of the state education system.

Further evidence of the incorporation of this industry into the state education system has been the introduction in 2003 of an export education levy and the establishment of an industry development fund. This levy is paid to the Ministry of Education by schools and other providers as a set percentage of gross foreign student tuition fee income. In October 2002, prior to introducing the levy, a discussion document was released by the Ministry of Education entitled, Developing Export Education - The Export Education Industry Development Fund and Levy. This document offers no educational rationale at all for what it refers to as "one of New Zealand's most exciting and rapidly growing industries" (Ministry of Education, 2002b, p. 3). The document is constructed almost entirely from a discourse of economics in which education is taken to be an internationally marketable commodity. According to the document:

The Government sees export education as an important contributor to New Zealand's economic well-being, and an industry that brings significant wider benefits in domestic education and in the development of international relations and trade. Importantly the export education industry is the sort of high value-added knowledge industry that has been identified as key to New Zealand's future. The Government wants to encourage and support the continued, sustained growth of export education. (Ministry of Education, 2002b, p. 7)

Although this statement makes passing reference to "significant wider benefits in domestic education", there is no elaboration within the document as to what these might be. The view presented clearly emphasises the economic benefits, and the document acknowledges that:

While export education brings a range of social and long-term benefits, it is primarily a commercial activity and most benefits go to the direct participants. (Ministry of Education, 2002b, p. 8)

Significantly, export education is conspicuously absent from other major Government policy documents on education. For instance, there is not a single reference to export education in the document,
Education Priorities for New Zealand, published by the Government in May 2003. This is further strong evidence that the international commercialisation of New Zealand's schools is being driven by economic rather than educational priorities.

As one facet of globalisation, export education raises important issues concerning the role of the state in education. Dale and Robertson, writing in 1997, suggest that as schools become less dependent on state funding, the state's control over public education is weakened. While the state may have the power to regulate, "there is a potential challenge to this state power in the ability of individual Boards of Trustees to authorize the recruitment of students from overseas which may again, at the margins, undermine the state's accountability for a crucial public service" (Dale \& Robertson, 1997, p. 223).

Concerns about the potential risks to state schooling have been steadily mounting. In November 2002, the New Zealand Post-Primary Teachers' Association, in a submission to the Ministry of Education on the proposed levy, argued for the numbers to be capped at five percent of the total roll for any state school. In calling for more research, they are reported as asserting that: "The 'export education' industry should not exist unless it is in a position to give an absolute assurance to the parents of New Zealand students that their children are not in any way disadvantaged by the industry" (Quirke, 2002).

The first empirical investigation of the impact of FFP students on schools has been undertaken by the Education Review Office (ERO) the agency responsible for the regular inspection and review of all New Zealand schools. In conducting its evaluation (Education Review Office, 2003) the ERO collected questionnaire data from all the schools with FFP students that were reviewed during Term 4, 2002 and Term 1,2003 . Additional information was collected on the quality of provisions for international students in each school reviewed. In all, data were drawn from 39 secondary and 55 primary schools where FFP students were enrolled. From these, 10 schools with higher numbers or proportions of FFP students were selected for more in-depth study.

The focus of the ERO report is on the extent to which schools are meeting the pastoral and educational needs of FFP students. The findings show that most schools are providing a satisfactory quality of educational experience for their foreign students and there is no evidence to suggest that these students are having a negative impact 
on the provision of education to domestic students (Education Review Office, 2003, pp. 33-34). Nevertheless, according to ERO, further information is required to evaluate how far schools may have become reliant on the income from foreign students and the impact this may have on the quality of education for domestic students (Education Review Ofice, 2003 , p. 1). While there are some indications of educational benefits for domestic students, such as increased awareness and knowledge of other cultures, the main benefits derive from the improvements in facilities and resources that result from the additional income received from FFP students. The report shows that almost 60 percent of the secondary schools and almost 30 percent of the primary schools surveyed responded that the income obtained from FFP students was very important to the school's operations.

The ERO findings not only confirm that many schools are becoming reliant on the income from FFP students, but they also show that schools with a socio-economic advantage are more likely than other schools to benefit from these commercial opportunities. This can be inferred from the data relating to high and low decile secondary schools, a distinction that relates to a socio-economic classification system introduced by the Ministry of Education in 1995. Under this system, all New Zealand secondary schools are given a decile classification, from 1 to 10 , based upon socio-economic indices derived from census data relating to the residential addresses of students enrolled at the school. Lower decile schools have a higher proportion of students from low income families with less job security and lower levels of parental education. They often also have higher numbers of Maori and Pacific Islands students. Higher decile schools have more students from higher income families with more job security and higher levels of parental education. The ERO survey data show that very few FFP students are enrolled in decile 1 or 2 schools (less than 5\%) compared to decile 9 and 10 schools (over 30\%). Thus, it is clear that the capacity of well resourced schools to market their services gives them a further advantage over schools that are less well resourced.

The situation emerging in New Zealand, where the commercialisation of public schools is exacerbating conditions of educational inequality, is at odds with the educational policy aims of the current New Zealand Government which was first elected in 1999 promising a new direction for education policy based upon the tenets of the "third way". This direction, it was claimed, would be found by abandoning the "market model" of education and ushering in a new era of nation-building in which public education would become the central platform upon which the state would build a more inclusive democratic society. That the Government still holds to this view, at least in its policy rhetoric, can be seen in the recent Statement of Education Priorities for New Zealand, which states, inter alia, that:

Education helps tear down barriers.... Education provides self-esteem and a sense of identity.... Education also helps to shape our unique culture.... It is at the heart of what it means to be a New Zealander and a global citizen in a changing world. (Ministry of Education, 2003, p. 1)

\section{Globalisation, Education and the GATS}

Globalisation and education comprise the dual mantras of third way politics, which has been the policy direction espoused by the Labour-led New Zealand Government. As with its British New Labour counterpart, the adoption of the third way is seen as an alternative both to the neoliberalism of the 1980s and 90s and to the "old style" socialism of the Keynesian welfare state. It rejects both the market fundamentalism of the former and the state domination of the latter. It emphasizes the renewal of civil society, inclusiveness and social responsibility, but also embraces individualism, economic freedom and globalisation (Giddens, 1998, 2000). The British Prime Minister, Tony Blair, asserted in March 2001 that "the ideas associated with the third way are still the wave of the future for progressive politics" (Blair, 2001, p. 3). Furthermore, in Blair's view, "Politics in all countries today is about how to combine dynamic markets with strong communities" (p. 9). However, critics of the third way (Hall, 1998; Hobsbawm, 1998; Callinicos, 2001) regard it as merely a "softer" version of neoliberalism. In Kelsey's words, it enables governments of the centre-left "to rationalise their role in consolidating neoliberalism" (Kelsey, 2002, p. 54). The third way, she argues, "is less a political theory than a programme of political management." It remains committed to the neoliberal agenda of globalisation, albeit globalisation with a social face.

The political goal of transforming New Zealand into a knowledge society, together with an acceptance of the inevitability of globalisation, presents a contradictory policy agenda for the Government. How can the effects of globalisation be reconciled with 
national and local concerns for social justice, participatory democracy, environmental sustainability and indigenous rights?

Globalisation is a many-faceted phenomenon which has now generated a considerable body of academic literature (Ohmae, 1995 Held, 1995; Hirst \& Thompson, 1996; Gray, 1998; Held et al., 1999; Germain, 2000; Rupert, 2000; Stiglitz, 2002). Although it has many different manifestations, globalisation has three main forms, all of which are inter-related. These are the economic, cultural and political forms of globalisation.

Political globalisation, in some accounts (Reich, 1991; Ohmae, 1995), is the most powerful form of globalisation because it is a process whereby the autonomy of the nation-state is being radically reduced and its sovereignty eroded. In some ways it is a consequential effect of other forms of globalisation. Thus, economic globalisation means that governments are required to manage monetary, fiscal and other economic processes, over which they have little or no control because they are no longer contained within national borders (Held, 1995). Likewise, cultural globalisation means that satellite communication systems can disseminate information, images and ideas with increasing degrees of freedom, opening up an enormous array of influences on socialisation and weakening the notion of "citizen" as a unified and unifying concept (Capella, 2000).

Within the context of political globalisation, the nation-state surrenders some of its capacity to ensure citizenship rights or entitlements, thus eroding other non-economic objectives such as a commitment to social welfare and the protection of the environment. It is in this area that globalisation can have its most harmful effects because there are no global agencies that can take the place of the nation-state (Hirst \& Thompson, 1996). Without any supranationa controls, globalisation positions people into three groups: those who globalise; those who are globalised; and those whom globalisation leaves out.

Those who globalise concentrate on capital, resources, knowledge and the control of information. Those who are globalised are "information poor" and "knowledge poor", workers and consumers. Those left out have little or no access to information and knowledge with no absorptive capacity as consumers and no relevance to production. (Hallak, 1998, p. 7)

There can be no doubt that, from this perspective, the knowledge economy and the knowledge society will serve the interests of those who globalise. Thus, when these are the central aims of public education, serious questions need to be asked about what has happened to the relationship between education and the nation-state and what this means for the education of indigenous peoples. What globalisation produces at the national level is a shift of focus away from citizenship as the primary purpose of education towards the full commercialization and commodification of public education.

Joseph Stiglitz, former chief economist of the World Bank and winner of the 2001 Nobel prize for economics, has recently argued that although globalisation has the potential to be a force for good, it has not worked for millions of people. He lays much of the blame for this squarely on the transnational economicinstitutions (Stiglitz, 2002, p. 214).

A major transnational agency that serves the interests of global capitalism is The World Trade Organisation (WTO). For some time, this agency has vigorously promoted free trade in material goods, resources and other commodities. More recently, the WTO has turned its attention to promoting open trade in services such as education. The General Agreement on Trade in Services (GATS) was initially adopted in 1994 as a global treaty with the aim of removing all barriers to trade in any service covered by the treaty. The range of services covered by this treaty is already very broad and there is a requirement for each WTO member to participate in successive rounds of negotiations to expand the scope of the GATS. There is no doubt that all levels of public education, from primary to tertiary, are services to which certain GATS rules could apply (Grieshaber-Otto \& Sanger, 2002).

Under the GATS, governments are required to extend the best trea tment that is given to a domestic service or service provider to any foreign service or service provider. Such a rule "aims to create a 'level playing field' so that there is no discrimination against foreign corporations entering the services market" (Rikowski, 2002, p. 7). As Kelsey (2002, p. 25) points out, "the corporate promoters of the GATS have a clear agenda to open up potentially lucrative public services to foreign providers, and guarantee them rights of access and ownership." Clearly, schools and other educational institutions are obvious targets for this form of global commercialisation whereby the interests of the nation-state would be subordinated to the interests of global capital. 
As a member of the WTO, the New Zealand government is under pressure for education to be included under the GATS (Grieshaber-Otto \& Sanger, 2002, p. 9). Although there is some opposition to this, particularly from the tertiary sector unions, there is a strong possibility, unless the opposition increases, that the present government will agree to this happening. If education services were to be covered by the GATS, the government would be unable to prevent foreign providers from offering services for profit in competition with local educational providers. The government would also be bound to offer similar subsidies to foreign providers. This presents a major threat to public education, as Rikowski argues with reference to what is happening to education in England:

The overall effect of these processes and developments for education is that the business takeover of education services is our future, unless we decide to provide clear limitations to the process. Education services will be progressively commercialized, privatized and capitalized. This is what "globalization" means for education, and this is the WTO's education agenda as pursued through the GATS, aided and abetted by Governments and promoted by corporate lobbying machines. (Rikowski, 2002, p. 2)

The prospect, eventually, of including education services under the GATS is made more likely by the fact that many of New Zealand's schools (both public and private) have been marketing their services internationally for more than a decade. The most recent round of GATS negotiations commenced in March 2003, and the inclusion of education was clearly on the agenda. In the lead-up to these negotiations, strong public concern was expressed and the New Zealand Government came under considerable domestic pressure, particularly from the tertiary sector unions, to ensure that education was excluded from the list of services it was willing to have included under the Agreement. Consequently, by invoking Article 1.3 Clause (b) of the GATS, education was deemed to be a service "supplied in the exercise of governmental authority" and was therefore not included in the New Zealand offer.

Article 1.3 of the GATS contains the following clauses:

"For the purposes of this Agreement...

(b) "services" includes any service in any sector except services supplied in the exercise of governmental authority;

(c) "a service supplied in the exercise of governmental authority" means any service which is supplied neither on a commercial basis, nor in competition with one or more service suppliers." [italics added]

There can be little doubt that public education services in New Zealand do not comply with Clause (c) of Article 1.3. On the face of it, it would seem most unlikely that the New Zealand Government wil be able to sustain its resistance to the inclusion of education in the GATS through to the conclusion of the current round of negotiations scheduled for January 1, 2005.

\section{Conclusion}

This paper has addressed a number of issues arising from the relationship between globalisation, the commercialisation of education and the policy dilemmas relating to the future of public education in New Zealand.

Historically, education in New Zealand has contributed directly to the maintenance of national identity and democratic citizenship as a central justification for the state's investment in public schooling. More recently, however, following the neoliberal revolution of the late 1980s with its policies of structural adjustment, education has been to a large extent commodified and commercialised. This trend has been accelerated as the Government has embraced economic globalisation and sought to create a knowledge-based economy. The assumption within this context, is that education services provided by the state can contribute directly to economic growth through foreign exchange earnings, international trade opportunities and local job creation.

The growth of the export education industry, in conjunction with the ominous requirements of the GATS, poses a major threat to the public education system that was initially designed to be free, accessible and universal. The politicians and policy makers promoting education as an industry appear to be oblivious to what is a fundamental clash of principles. The following comment, made in the Canadian context, succinctly and forcefully expresses this concern:

There are underlying tensions between the widely recognized aims of public education and the principles of the GATS. Instead of seeing universal access to quality public education as a crucial investment in the social and economic health of any democracy, the GATS treats education as just another service sector potentially available for commercial exploitation. By consolidating and augmenting pressures for commercialisation and privatisation, the 
GATS undermines public education's central principles of affordability, accessibility, and universality. (Grieshaber-Otto \& Sanger, 2002, pp. 76-77)

\section{References}

Asia 2000 Foundation. (2003, April). The export education industry: Challenges for New Zealand. Wellington: Asia 2000 Foundation.

Blair, T. (2001). Third way, phase two, Socialist Renewal, New Series, 4, 3-9.

Callinicos, A. (2001). Against the third way. Cambridge: Polity Press.

Capella, J-R. (2000). Globalization, a fading citizenship. In N. C. Burbules \& C. A. Torres (Eds.), Globalization and education: Critical perspectives (pp. 227-251). London: Routledge.

Codd, J., Gordon, L., \& Harker, R. (1997). Education and the role of the state: Devolution and control Post-Picot. In A. H. Halsey, H. Lauder, P. Brown \& A. S. Wells (Eds.), Education: Culture, economy and society (pp. 263-272). Oxford: Oxford University Press.

Dale, R., \& Robertson, S. (1997). "Resiting" the nation, "reshaping" the state: Globalization effects on education policy. In M. Olssen \& K. Morris Matthews (Eds.), Education policy in New Zealand: The 1990s and beyond (pp. 209-227). Palmerston North: Dunmore Press.

Easton, B. (1999). The whimpering of the state. Auckland: Auckland University Press.

Education Review Office (ERO). (2003, June). Foreign fee-paying students in New Zealand schools. Wellington: ERO.

Fiske, E. B. \& Ladd, H. F. (2000). When schools compete: A cautionary tale. Washington, D.C.: Brookings Institution Press.

Germain, R. D. (Ed.). (2000). Globalization and its critics: Perspectives from political economy. London: Macmillan.

Giddens, A. (1998). The third way: The renewal of social democracy. Cambridge: Polity Press.

Giddens, A. (2000). The third way and its critics. Cambridge: Polity Press.

Gray, J. (1998). False dawn: The delusions of global capitalism. London: Granta Books.
Grieshaber-Otto, J. \& Sanger, M. (2002). Perilous lessons: The impact of the WTO Services Agreement (GATS) on Canada's public education system. Ottawa: Canadian Centre for Policy Alternatives.

Grunwell, R. (2003, August 17). Sick troubled students allowed to stay here. Sunday Star Times, p. 1.

Hall, S. (1998, November/December). The great moving nowhere show. Marxism today: Special issue, 9-14.

Hallak, J. (1998). Education and globalization. Paris: International Institute for Educational Planning, UNESCO.

Held, D. (1995). Democracy and the global order: From the modern state to cosmopolitan governance. Cambridge: Polity Press.

Held, D., McGrew, A., Goldblatt, D., \& Perraton, J. (1999). Global transformations - politics, economics and culture. Cambridge: Polity Press.

Hirsch, F. (1976). Social limits to growth. Cambridge: Harvard University Press.

Hirst, P., \& Thompson, G. (1996). Globalization in question: The international economy and the possibilities of governance. Cambridge: Polity Press.

Hobsbawm, E. (1998, November/December). The big picture: The death of neoliberalism. Marxism today: Special issue, 4-8.

Kelsey, J. (2002). At the crossroads: Three essays. Wellington: Bridget Williams Books.

Marginson, S. (1993). Education and public policy in Australia. Cambridge: Cambridge University Press.

Marginson, S. (1997a). Is economics sufficient for the government of education? New Zealand Journal of Educational Studies, 32(1), 3-12.

Marginson, S. (1997b). Markets in education. Sydney: Allen and Unwin.

Ministry of Education. (1991). Education policy: Investing in people, our greatest asset. Wellington: Government Printer.

Ministry of Education. (2001). Export education in New Zealand: A strategic approach to developing the sector. Wellington: Ministry of Education.

Ministry of Education. (2002a). Code of practice for the pastoral care of international students (Revised July 2003). Wellington: Ministry of Education. 
Ministry of Education. (2002b). Developing export education - The export education industry development fund and levy. Discussion document. Wellington: Ministry of Education.

Ministry of Education. (2003). Statement of education priorities for New Zealand. Wellington: Ministry of Education.

Nash, T. (2003, May 22). City schools looking for overseas aid. Manawatu Standard, p. 3.

Ohmae, K. (1995). The end of the nation state: The rise of regional economies. London: Harper Collins.

Quirke, M. (2002, November 21) Call for cap on foreign student numbers. Dominion Post, p. 5.

Reich, R. (1991). The work of nations: Preparing ourselves for 21st-Century capitalism. New York: Knopf.

Rikowski, G. (2002). Globalization and education. A paper prepared for the House of Lords Select Committee on Economic Affairs, Inquiry into the Global Economy, mimeo.

Rupert, R. (2000). Ideologies of globalization: Contending visions of a new world order. London: Routledge.

Shepheard, N. (2002, July). Schools for sale. North and South, pp. 56-64.

Smelt, S. (1998). Today's schools: Governance and quality. Wellington: Victoria University Institute of Policy Studies.

Stiglitz, J. E. (2002). Globalization and its discontents. New York: Norton $\&$ Co.

The Treasury. (1987). Government management: Brief to the incoming government 1987. Vols. $1 \&$ 2. Wellington: Government Printer.

\section{The author}

John Codd is Professor of Policy Studies in Education at Massey University College of Education. He has co-edited several books on New Zealand education and his research on educational reform has been published in international journals. He is co-author (with Mark Olssen and Anne-Marie O'Neill) of Education Policy: Globalization, Citizenship and Democracy (Sage Publications, London, 2004) His current research interests include higher education policy and the implications of globalisation for education. 